\title{
Soil respiration at mean annual temperature predicts annual total across vegetation types and biomes
}

\author{
M. Bahn ${ }^{1}$, M. Reichstein ${ }^{2}$, E. A. Davidson ${ }^{3}$, J. Grünzweig ${ }^{4}$, M. Jung ${ }^{2}$, M. S. Carbone ${ }^{5}$, D. Epron ${ }^{6}$, L. Misson ${ }^{7, \dagger}$,

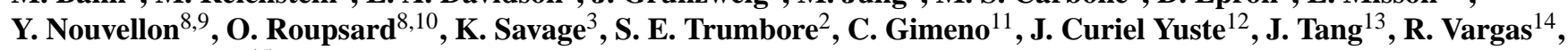 \\ and I. A. Janssens ${ }^{15}$ \\ ${ }^{1}$ Institute of Ecology, University of Innsbruck, Innsbruck, Austria \\ ${ }^{2}$ Max-Planck Institute for Biogeochemistry, Jena, Germany \\ ${ }^{3}$ The Woods Hole Research Center, Falmouth, Massachusetts, USA \\ ${ }^{4}$ Hebrew University of Jerusalem, Robert H. Smith Faculty of Agriculture, Food and Environment, Rehovot, Israel \\ ${ }^{5}$ Department of Geography, University of California, Santa Barbara, California, USA \\ ${ }^{6}$ Nancy Université, Université Henri Poincaré, Vandoeuvre les Nancy, France \\ ${ }^{7}$ CNRS, Montpellier, France \\ ${ }^{8}$ CIRAD, Montpellier, France \\ ${ }^{9}$ CRDPI, Pointe-Noire, Republic of Congo \\ ${ }^{10}$ CATIE, Turrialba, Costa Rica \\ ${ }^{11}$ CEAM, Paterna, Valencia, Spain \\ ${ }^{12}$ CREAF, Universitat Autònoma de Barcelona, Bellaterra, Barcelona, Spain \\ ${ }^{13}$ The Ecosystems Center, Marine Biological Laboratory, Woods Hole, Massachusetts, USA \\ ${ }^{14}$ Department of Environmental Science, Policy \& Management (ESPM), University of California, Berkeley, California, USA \\ ${ }^{15}$ Department of Biology, University Instelling Antwerp, Wilrijk, Belgium \\ ${ }^{\dagger}$ This article is dedicated to Laurent Misson, who died in a tragic accident in March 2010.
}

Received: 12 November 2009 - Published in Biogeosciences Discuss.: 11 December 2009

Revised: 29 May 2010 - Accepted: 4 June 2010 - Published: 9 July 2010

\begin{abstract}
Soil respiration (SR) constitutes the largest flux of $\mathrm{CO}_{2}$ from terrestrial ecosystems to the atmosphere. However, there still exist considerable uncertainties as to its actual magnitude, as well as its spatial and interannual variability. Based on a reanalysis and synthesis of 80 site-years for 57 forests, plantations, savannas, shrublands and grasslands from boreal to tropical climates we present evidence that total annual SR is closely related to SR at mean annual soil temperature (SR $\mathrm{SRT}_{\mathrm{MAT}}$ ), irrespective of the type of ecosystem and biome. This is theoretically expected for non water-limited ecosystems within most of the globally occurring range of annual temperature variability and sensitivity $\left(Q_{10}\right)$. We further show that for seasonally dry sites where annual precipitation $(P)$ is lower than potential evapotranspiration (PET), annual SR can be predicted from wet season
\end{abstract}

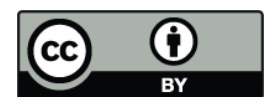

Correspondence to: $\mathrm{M}$. Bahn (michael.bahn@uibk.ac.at)
$\mathrm{SR}_{\mathrm{MAT}}$ corrected for a factor related to $P / \mathrm{PET}$. Our finding indicates that it can be sufficient to measure $\mathrm{SR}_{\mathrm{MAT}}$ for obtaining a well constrained estimate of its annual total. This should substantially increase our capacity for assessing the spatial distribution of soil $\mathrm{CO}_{2}$ emissions across ecosystems, landscapes and regions, and thereby contribute to improving the spatial resolution of a major component of the global carbon cycle.

\section{Introduction}

In view of its implications for the climate system, the carbon (C) cycle has received increasing attention over the recent years (Denman et al., 2007). Recent global estimates suggest that soils emit about $98 \mathrm{Pg} \mathrm{C}$ per year, which exceeds emission rates from fossil fuel combustion by an order of magnitude (Bond-Lamberty and Thomson, 2010; Denman et al., 2007). While indicating that soils are the

Published by Copernicus Publications on behalf of the European Geosciences Union. 
predominant source of $\mathrm{CO}_{2}$ from terrestrial ecosystems, such estimates are still highly uncertain. They are based on a highly restricted dataset, which heavily underrepresents not only many biomes, but also the considerable spatial and temporal variability of SR within any given biome. Recently, progress has been made in illuminating factors determining the diurnal, seasonal and interannual variability of SR within ecosystems (Bahn et al., 2010; Davidson et al., 2006a; Vargas et al., 2010). At the same time we still lack tools permitting a rapid assessment of the spatial variability of SR across ecosystems, landscapes and regions - which would be essential for deriving more defensible regional and global estimates of SR.

It is evident that, even within short distance, similar types of ecosystems may exhibit substantial differences in annual SR (Bahn et al., 2008; Curiel Yuste et al., 2004; Kang et al., 2003, Vincent et al., 2006). Spatial assessments of total annual SR ( $\mathrm{SR}_{\text {annual }}$ ) are difficult to achieve given a finite availability of resources and the resulting trade-off between the temporal resolution required for obtaining an annual estimate and the spatial coverage required for achieving a defensible regional up-scaling (Savage and Davidson, 2003). For this reason it has been attempted to identify proxies for estimating $\mathrm{SR}_{\text {annual }}$, including monthly air temperature and precipitation (Raich and Potter, 1995; Raich et al., 2002), litterfall (Davidson et al., 2002; Raich and Nadelhoffer, 1989) and productivity indices, such as leaf area index or gross primary productivity (Bahn et al., 2008; Hibbard et al., 2005; Janssens et al., 2001; Reichstein et al., 2003).

Here, we demonstrate that SR measured at mean annual temperature $\left(\mathrm{SR}_{\mathrm{MAT}}\right)$ may be a useful and meaningful predictor of $\mathrm{SR}_{\text {annual }}$. We do so by first outlining a theoretical framework, suggesting that $\mathrm{SR}_{\mathrm{MAT}}$ is in principle well suited for estimating $\mathrm{SR}_{\text {annual }}$ at non water-limited sites within most of the globally occurring range of annual soil temperature variability and temperature sensitivity of SR $\left(Q_{10}\right)$. Secondly, we apply a Monte-Carlo analysis to test the hypothesized relationship between $\mathrm{SR}_{\mathrm{MAT}}$ and $\mathrm{SR}_{\text {annual }}$ on a randomly generated dataset. Thirdly, we explore the relationship for existing databases of SR for 57 forests, plantations, savannas, shrublands and grasslands from boreal to tropical climates. We show that for seasonally dry ecosystems, where mean annual temperature occurs only in the wet season, $\mathrm{SR}_{\text {annual }}$ can be estimated from wet season $\mathrm{SR}_{\mathrm{MAT}}$ and a correction factor based on the ratio of precipitation to potential evapotranspiration. Finally, based on additional 23 siteyears for four temperate forests, we analyse effects of interannual variability on estimates of $\mathrm{SR}_{\text {annual. }}$ Our finding indicates that it is sufficient to measure $\mathrm{SR}_{\mathrm{MAT}}$ for obtaining a highly constrained estimate of its annual total, which could help improving future assessments of the spatial distribution of soil $\mathrm{CO}_{2}$ emissions across ecosystems, landscapes and regions.

\section{Methods}

\subsection{Annual soil temperature variability across biomes}

A global overview of the annual variability of soil temperature, expressed as the standard deviation of daily means of soil temperature $\left(T_{\mathrm{sd}}\right)$, was obtained from the FLUXNET data set (http://www.fluxdata.org/default.aspx) and included all sites reporting continuous quality-controlled data for soil temperature which were made available by the site principal investigators. In total 172 sites and 474 site-years were included in the analysis. Sites were grouped to the following climatic zones: tropical (7 sites), dry (6 sites), subtropicalmediterranean (47 sites), temperate (49 sites), temperate continental (35 sites), boreal (24 sites) and arctic climates (4 sites). For sites reporting multiple years of soil temperature an average $T_{\mathrm{sd}}$ of all reported years was used.

\subsection{Soil respiration database}

The soil respiration database consisted of 35 sites and 58 siteyears for temperate and boreal forests and grasslands, 7 tropical forests and plantations, and 15 mediterranean, dry subhumid and semi-arid forests, savannas, grasslands and shrublands, as summarized in Table 1 . The database also includes 11 previously unpublished datasets, which were obtained using a range of closed and open dynamic soil respiration systems on previously installed shallow collars. All these systems are well established systems that are either commercially available (Licor, Lincoln, Nebraska, USA) or have been tested and described in further detail in previous studies (Rayment and Jarvis, 1997; Carbone et al., 2008). Measurements were taken either manually in bi-weekly to monthly intervals or continuously, using automated soil respiration systems. Details on the systems used at the respective sites, and on sampling frequencies and spatial replication are provided in Table 2. In parallel to soil respiration measurements, soil temperature (using soil temperature probes) and soil moisture (using TDR probes) were recorded mostly in $5 \mathrm{~cm}$ depth.

$\mathrm{SR}_{\mathrm{MAT}}$, i.e. the rates of soil respiration occurring at mean annual soil temperature, for all sites and years were calculated using the soil temperature - respiration response functions reported by the respective studies. The average annual temperature sensitivity of SR, expressed as $Q_{10}$, has been listed for all sites in Table 1. For some tropical sites with minor seasonal differences in soil temperature and for several seasonally dry ecosystems no well constrained or meaningful (cf. e.g. Davidson et al., 2006) $Q_{10}$ value could be provided. Calculated SR $\mathrm{SAT}_{\mathrm{T}}$ was cross-checked against SR values actually measured at MAT. The annual variability of soil temperature $\left(T_{\mathrm{sd}}\right)$ was calculated from the original data records as the standard deviation of daily means of soil temperature for the reported years. 
Table 1. Vegetation type, location, mean and standard deviation of annual soil temperature (as based on daily means), mean annual precipitation (MAP), ratio of precipitation/potential evapotranspiration (P/PET), as extracted from a global grid model, $Q_{10}$ of soil respiration, soil respiration at mean annual temperature $\left(\mathrm{SR}_{\mathrm{MAT}}\right.$ - wet season values are set in italics) and annual soil respiration $\left(\mathrm{SR}_{\mathrm{annual}}\right)$ for the sites included in this study. Sources: 1 . . Bahn et al., 2008; 2. . Janssens et al., 2001 and 2003; 3. . Curiel Yuste et al., 2004; 4 ... Janssens and Pilegaard, 2003; 5... Savage et al., 2009; 6...Davidson et al. 2006c, and some additional unpublished data from Savage and Davidson; 7... Davidson et al., 2006b, and some additional unpublished data from Savage and Davidson; 8...Roupsard and Epron, unpublished ; 9...Salimon et al., 2004; 10... Davidson et al., 2008; 11...Davidson et al., 2000; 12...Nouvellon and Epron, unpublished; 13...Nouvellon and Epron, unpublished; 14... Misson, unpublished; 15...Gimeno et al., unpublished; 16...Tang and Baldocchi, 2005; 17... Wieser et al., 2009; 18...Carbone and Trumbore, unpublished; 19... Vargas and Allen, 2008; 20...Grünzweig et al., 2009; 21... Talmon and Grünzweig, unpublished.

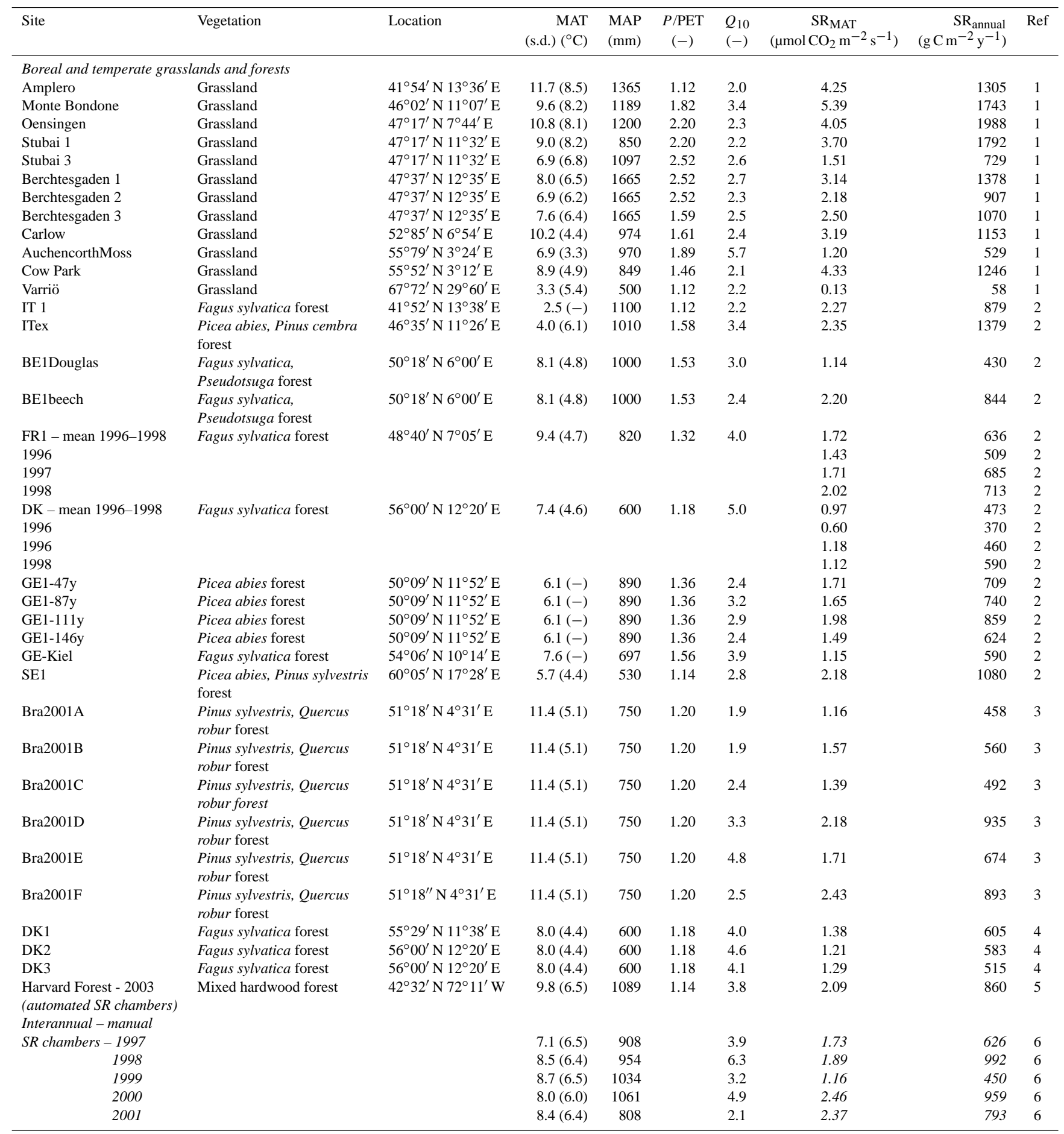


Table 1. Continued.

\begin{tabular}{|c|c|c|c|c|c|c|c|c|c|}
\hline Site & Vegetation & Location & $\begin{array}{r}\text { MAT } \\
\text { (s.d.) }\left({ }^{\circ} \mathrm{C}\right)\end{array}$ & $\begin{array}{l}\text { MAP } \\
(\mathrm{mm})\end{array}$ & $\begin{array}{c}P / \mathrm{PET} \\
(-)\end{array}$ & $\begin{array}{l}Q_{10} \\
(-)\end{array}$ & $\begin{array}{c}\mathrm{SR}_{\mathrm{MAT}} \\
\left(\mu \mathrm{mol} \mathrm{CO} \mathrm{m}^{-2} \mathrm{~s}^{-1}\right)\end{array}$ & $\begin{array}{r}\mathrm{SR}_{\text {annual }} \\
\left(\mathrm{g} \mathrm{C} \mathrm{m}^{-2} \mathrm{y}^{-1}\right)\end{array}$ & Ret \\
\hline 2002 & & & $7.0(6.3)$ & 1111 & & 3.5 & 2.43 & 979 & 6 \\
\hline 2003 & $\mathrm{~V}$ & $8.6(6.3)$ & 1310 & & 4.4 & 2.41 & 958 & 6 & \\
\hline 2005 & & & $8.5(7.2)$ & 1426 & & 4.3 & 1.83 & 893 & 6 \\
\hline 2006 & & & $8.9(6.3)$ & 1095 & & 3.8 & 1.72 & 796 & 6 \\
\hline 2007 & & & $8.9(8.4)$ & 1139 & & 4.8 & 1.64 & 825 & 6 \\
\hline 2008 & & & $9.1(6.3)$ & 1565 & & 2.4 & 2.37 & 921 & 6 \\
\hline $\begin{array}{l}\text { Interannual - manual } \\
\text { SR chambers }-2000\end{array}$ & & & $6.1(6.1)$ & 767 & & 4.5 & 2.20 & 747 & 7 \\
\hline 2001 & & & $7.8(5.6)$ & 524 & & 2.9 & 2.47 & 754 & 7 \\
\hline 2002 & & & $7.8(6.2)$ & 798 & & 2.7 & 2.30 & 701 & 7 \\
\hline 2003 & & & $7.1(6.9)$ & 952 & & 3.2 & 2.59 & 857 & 7 \\
\hline 2004 & & & $7.0(6.4)$ & 763 & & 3.7 & 2.61 & 752 & 7 \\
\hline 2005 & & & $7.1(6.9)$ & 1280 & & 4.0 & 2.50 & 788 & 7 \\
\hline Vanuatu & Coco plantation & $15^{\circ} 27^{\prime} \mathrm{S} 167^{\circ} 12^{\prime} \mathrm{E}$ & $26.6(1.4)$ & 2760 & 2.60 & 1.0 & 5.00 & 1917 & 8 \\
\hline Rio Branco & Rainforest & $9^{\circ} 56^{\prime} \mathrm{S} 67^{\circ} 52^{\prime} \mathrm{W}$ & $23.8(0.8)$ & 1940 & 1.24 & 5.6 & 4.73 & 1620 & 9 \\
\hline Tapajos & Rainforest & $2^{\circ} 90^{\prime} \mathrm{S} 54^{\circ} 95^{\prime} \mathrm{W}$ & $26.0(-)$ & 2090 & 1.50 & - & 3.38 & 1279 & 10 \\
\hline Paragominas & Primary forest & $2^{\circ} 59^{\prime} \mathrm{S} 47^{\circ} 31^{\prime} \mathrm{W}$ & $23.0(0.7)$ & 1784 & 1.50 & 1.0 & 5.24 & 2000 & 11 \\
\hline Itatinga & Eucalytus plantation & $23^{\circ} 01^{\prime} \mathrm{S} 48^{\circ} 32^{\prime} \mathrm{W}$ & $19.1(2.0)$ & 1360 & 1.01 & - & 3.13 & 1071 & 12 \\
\hline Kondi & Eucalytus plantation, $5 \mathrm{y}$ & $4^{\circ} 35^{\prime} \mathrm{S} 11^{\circ} 75^{\prime} \mathrm{E}$ & $25.8(2.0)$ & 1400 & 1.27 & - & 1.31 & 465 & 13 \\
\hline Kondi & Eucalytus plantation, $13 \mathrm{y}$ & $4^{\circ} 35^{\prime} \mathrm{S} 11^{\circ} 75^{\prime} \mathrm{E}$ & $25.8(2.0)$ & 1400 & 1.27 & - & 2.13 & 744 & 13 \\
\hline \multicolumn{10}{|c|}{ Mediterranean, subhumid and semiarid forests, savannas, shrublands and grasslands } \\
\hline Puechabon & Quercus forest & $43.7414 \mathrm{~N} 3.59583 \mathrm{E}$ & $12.3(5.4)$ & 844 & 1.00 & 1.9 & 2.73 & 762 & 14 \\
\hline Alinya & Grassland & $42^{\circ} 12^{\prime} \mathrm{N} 1^{\circ} 27^{\prime} \mathrm{E}$ & $8.5(7.8)$ & 700 & 0.81 & 2.1 & 1.99 & 494 & 1 \\
\hline IT2 & Quercus ilex forest & $41^{\circ} 45^{\prime} \mathrm{N} 12^{\circ} 22^{\prime} \mathrm{E}$ & $14.5(5.5)$ & 770 & 0.73 & 2.0 & 5.87 & 1456 & 2 \\
\hline Las Majadas del Tietar & Quercus ilex savanna & $39^{\circ} 56^{\prime} \mathrm{N} 5^{\circ} 46^{\prime} \mathrm{W}$ & $19.2(10.1)$ & 528 & 0.64 & 2.5 & 3.08 & 683 & 15 \\
\hline Savanna grassland open & Savanna grass & $38^{\circ} 43^{\prime} \mathrm{N} 120^{\circ} 96^{\prime} \mathrm{W}$ & $17.7(6.9)$ & 496 & 0.46 & 1.1 & 1.60 & 394 & 16 \\
\hline Savanna trees & Quercus douglasii & $38^{\circ} 43^{\prime} \mathrm{N} 120^{\circ} 96^{\prime} \mathrm{W}$ & $17.7(6.9)$ & 496 & 0.46 & 1.2 & 2.15 & 616 & 16 \\
\hline
\end{tabular}

\subsection{Monte Carlo analysis}

Monte Carlo methods are a class of computational algorithms that rely on repeated random sampling to compute their results. Here, we used a Monte Carlo analysis for theoretically testing the hypothesized relationship between $\mathrm{SR}_{\mathrm{MAT}}$ and $\mathrm{SR}_{\text {annual }}$ for random combinations of $\mathrm{SR}_{\mathrm{MAT}}, T_{\mathrm{sd}}$ and $Q_{10}$, constrained to a range of values commonly occurring across the globe (see also Table 1 and Fig. 2). Our analysis was based on 1000 random combinations of $\mathrm{SR}_{\mathrm{MAT}}$ (range $\left.0-8.0 \mu \mathrm{mol} \mathrm{m}^{-2} \mathrm{~s}^{-1}\right), T_{\mathrm{sd}}\left(2-15^{\circ} \mathrm{C}\right)$ and $Q_{10}(1.0-$ 6.0). The variables were generated from independent Gaussian distributions with the following means and standard deviations, which were derived from the available field data: 2.66 (s.d. $=0.98$ ) for $Q_{10}, 2.89$ (1.48) for $\mathrm{SR}_{\mathrm{MAT}}$, and 6.7 (1.8) for $T_{\text {sd. }}$.

\subsection{Aridity index}

A generally comparable aridity index for all sites was derived by relating estimates of precipitation $(P)$ to estimates of potential evaporation (PET), which were obtained as follows. Potential evapotranspiration was calculated according to the Modified-Hargreaves method (Droogers and Allen, 2002). This method uses potential radiation (top of atmosphere), average air temperature $(2 \mathrm{~m})$, the diurnal temperature range as well as precipitation as predictors. Global monthly grids at $0.5^{\circ}$ resolution were calculated and extracted for each site from the grid cell closest to the site. Air temperature grids were derived from CRU (Climate Research Unit) climate data (New et al., 2002), homogenized and extended to 2007 (Österle et al., 2003). Precipitation data were obtained from the GPCC project (Global Global Preciptiation Climatology 
Table 2. Methods for measuring soil respiration for previously unpublished datasets. References as in Table 1. CDS and ODS refer to closed and open dynamic system, respectively.

\begin{tabular}{|c|c|c|}
\hline Site (Reference) & System and instrumentation & Replication, sampling frequency \\
\hline Vanuatu (7) & $\begin{array}{l}\text { CDS, Li-6000-09 chamber + Li-6200 } \\
\text { (Licor) }\end{array}$ & 64 collars, monthly \\
\hline Itatinga (11) & $\begin{array}{l}\text { CDS, Li8100-103 survey chamber } \\
\text { + Li8100 Licor, (Licor) }\end{array}$ & 27 collars $(20 \mathrm{~cm})$, bi-weekly \\
\hline Kondi (12) & $\begin{array}{l}\text { CDS, Li8100-102 survey chamber + } \\
\text { Li8100 (Licor) }\end{array}$ & 27 collars $(10 \mathrm{~cm})$, bi-weekly \\
\hline Puechabon (13) & ODS (cf. Rayment and Jarvis, 1997) & 4-12 chambers, continuous \\
\hline Las Majadas del Tietar (14) & $\begin{array}{l}\text { ODS (cf. Rayment and Jarvis, 1997), } \\
\text { Li6262 (Licor) }\end{array}$ & 6 chambers, continuous \\
\hline James Reserve forest (18) & CDS, as in (Carbone et al., 2008) & 8 chambers, continuous \\
\hline $\begin{array}{l}\text { Semi-arid and dry subhumid } \\
\text { shrublands (20) }\end{array}$ & CDS, LI-6400-09 + Li-6400 (Licor) & 10 collars, bi-weekly to monthly \\
\hline
\end{tabular}

Centre; cf. gpcc.dwd.de for documentation). For each location potential evapotranspiration and precipitation were extracted for 27 years (1982-2008) and averaged on a monthly and an annual basis. Extracted mean annual precipitation closely matched the values reported for the sites (Table 1; $\left.\mathrm{MAP}_{\text {predicted }}=1.02 \cdot \mathrm{MAP}_{\text {measured }}, R^{2}=0.88\right)$.

\section{Results and discussion}

\subsection{Theoretical considerations}

Major drivers of SR include abiotic (temperature, soil moisture) and biotic (gross primary productivity) factors (Bahn et al., 2009; Davidson et al., 2006a; Trumbore, 2006). Even though differences in SR across sites are largely determined by productivity, both of these fluxes increase with temperature. Therefore soil temperature $(T)$ typically suffices to explain most of the seasonal variation of SR in ecosystems without extended periods of drought (Bahn et al., 2008; Hibbard et al., 2005; Janssens et al., 2001; Reichstein et al., 2003). Thus, $\mathrm{SR}_{\text {annual }}$ of these sites can be estimated from a temperature response function, as based on SR at a reference temperature, the temperature sensitivity of SR ( $Q_{10}$, the factor by which SR is multiplied when the temperature increases by $10^{\circ} \mathrm{C}$ ) and the seasonal course of $T$. We define the mean annual temperature occurring at any site as the reference temperature, which permits the most generalized testing of our hypothesis across different climates.

Theoretically, if $T$ is constant throughout the year (i.e. its standard deviation is 0 ), $Q_{10}$ will have no effect on $\mathrm{SR}_{\text {annual }}$. In this case $\mathrm{SR}$ at mean annual temperature $\left(\mathrm{SR}_{\mathrm{MAT}}\right)$ scales directly to $\mathrm{SR}_{\text {annual, }}$ and their ratio expressed on the same basis (i.e. mean $\mathrm{SR}_{\text {annual }} / \mathrm{SR}_{\mathrm{MAT}}$ ) equals 1 (Fig. 1). As the seasonal amplitude of temperature $\left(T_{\mathrm{sd}}\right.$, defined as the standard deviation of daily mean soil temperature over the course

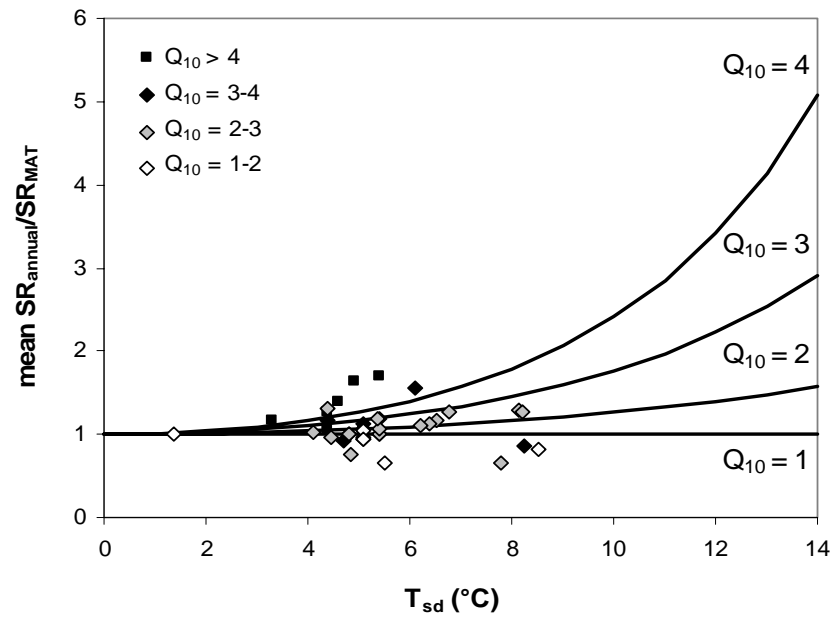

Fig. 1. The ratio of mean annual soil respiration (mean $\mathrm{SR}_{\text {annual }}$, $\mu \mathrm{mol} \mathrm{m} \mathrm{m}^{-2} \mathrm{~s}^{-1}$ ) over soil respiration at mean annual temperature $\left(\mathrm{SR}_{\mathrm{MAT}}, \mu \mathrm{mol} \mathrm{m} \mathrm{m}^{-2} \mathrm{~s}^{-1}\right)$ as affected by the annual variation of soil temperature $\left(T_{\mathrm{sd}}\right)$ and $Q_{10}$ of the temperature - soil respiration relationship. Data points indicate values of the non water-limited sites for mean $\mathrm{SR}_{\text {annual }} / \mathrm{SR}_{\mathrm{MAT}}, T_{\mathrm{sd}}$ and $Q_{10}$ classes.

of the year) increases, $Q_{10}$ becomes increasingly important because the temperature response of SR is not linear. Hence the degree to which $Q_{10}$ affects mean $\mathrm{SR}_{\text {annual }} / \mathrm{SR}_{\mathrm{MAT}}$ increases with increasing $T_{\text {sd }}$ (Fig. 1). A recently emerging global dataset of sites (FLUXNET; http://www.fluxdata.org/ default.aspx; Baldocchi, 2008) indicates that $T_{\text {sd }}$ increases from tropical to temperate and continental climates (Fig. 2). The median of $T_{\mathrm{sd}}$ was $0.7^{\circ} \mathrm{C}$ at tropical sites and between 5.5 and $7.4^{\circ} \mathrm{C}$ in all other climates, $95 \%$ of all values being lower than $10.1^{\circ} \mathrm{C}$. Exceptionally high values of $T_{\text {sd }}$ exceeding $10.5^{\circ} \mathrm{C}$ occurred in three non-forested ecosystems, two of which were burned open shrubland. Thus $T_{\mathrm{sd}}$ normally 


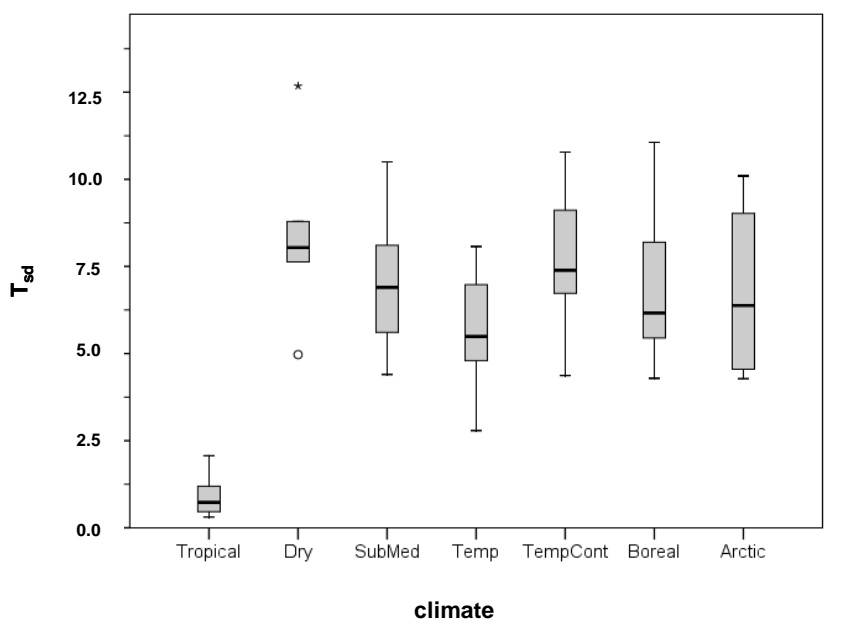

Fig. 2. Annual variation of soil temperature $\left(T_{\mathrm{sd}}\right)$ in different climatic regions. Boxplots for 172 Fluxnet sites as grouped to the different bioclimatic regions. $n=7,6,47,49,35,24$ and 4 for tropical, dry, subtropical/Mediterranean, temperate, temperate continental, boreal and arctic climates, respectively.

remains well within the range where $Q_{10}$ exerts a minor influence on the relationship between $\mathrm{SR}_{\mathrm{MAT}}$ and $\mathrm{SR}_{\text {annual }}$ (Fig. 1).

$Q_{10}$ values measured in situ have been reported to be normally in the range of 2-4 (Davidson et al., 2006a; Kirschbaum, 2006). Similarly, for the non-water limited temperate and boreal sites reported in this study $Q_{10}$ was between 1.9 and $5.7,90 \%$ of the values ranging between 2 and 5 (Table 1). To visualize the range of $T_{\mathrm{sd}}, Q_{10}$ and mean $\mathrm{SR}_{\text {annual }} / \mathrm{SR}_{\mathrm{MAT}}$ for the non-water-limited sites of our study in relation to the theoretical relationships, the respective data were included in Fig. 1. For clarity of the graph, $Q_{10}$ was grouped to classes of $1-2,2-3,3-4$ and $>4$. When the observed values match the theoretical relationship very closely, reported $Q_{10}$ values of 1-2 should thus fall in between the lines depicted for $Q_{10}=1$ and 2, and so on. The correspondence between data points and theoretical lines is generally poor. However, Fig. 1 clearly shows that $T_{\text {sd }}$ falls in a range where $Q_{10}$ is theoretically expected to have a minor effect on mean $\mathrm{SR}_{\text {annual }} / \mathrm{SR}_{\mathrm{MAT}}$. Therefore, we hypothesize that $\mathrm{SR}_{\mathrm{MAT}}$ and $\mathrm{SR}_{\text {annual }}$ are generally well coupled across non water-limited sites.

Using a Monte Carlo analysis we tested the hypothesized relationship between $\mathrm{SR}_{\mathrm{MAT}}$ and $\mathrm{SR}_{\text {annual }}$ for 1000 random combinations of $\mathrm{SR}_{\mathrm{MAT}}, T_{\mathrm{Sd}}$ and $Q_{10}$, constrained to a range of values commonly occurring across the globe (cf. methods). Our results confirm that such a relationship is theoretically likely to exist and indicate that only very few (i.e. ca. 10 out of 1000) random combinations of exceptionally high $T_{\mathrm{sd}}$ and $Q_{10}$ will result in marked deviations from an overall relationship (Fig. 3). This does not reflect a bias in the Monte Carlo analysis, but is fully consistent with what is to be

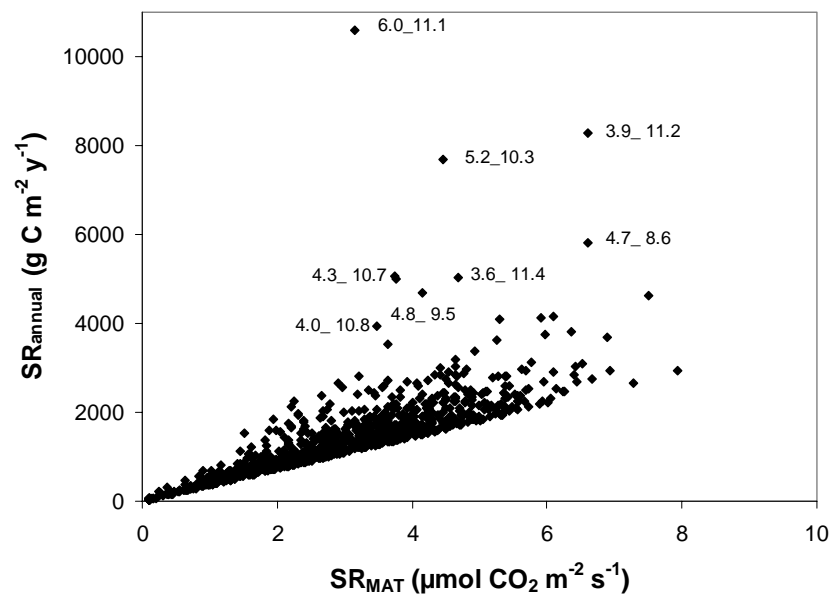

Fig. 3. Hypothetical relationship between soil respiration at mean annual temperature $\left(\mathrm{SR}_{\mathrm{MAT}}\right)$ and total soil annual respiration $\left(\mathrm{SR}_{\text {annual }}\right)$ for 1000 random combinations of $\mathrm{SR}_{\mathrm{MAT}}, T_{\mathrm{sd}}$ and $Q_{10}$, as obtained by a Monte Carlo simulation. Regression: $\mathrm{SR}_{\text {annual }}=455.8 \mathrm{SR}_{\mathrm{MAT}}^{1.0054}, R^{2}=0.94, p<0.001$. Numbers in graph indicate $Q_{10}$ and $T_{\mathrm{sd}}$ for exceptionally high values of $\mathrm{SR}_{\text {annual }}$.

theoretically expected (Fig. 1), because of the non-linearity of the respiration response to temperature. However, would the suggested relationship between $\mathrm{SR}_{\mathrm{MAT}}$ and $\mathrm{SR}_{\text {annual }}$ also occur in and across real ecosystems? If so, very few measurements of SR around the mean annual temperature would be sufficient to estimate $\mathrm{SR}_{\text {annual }}$.

\subsection{Inter-site relationships}

We tested the hypothesis first on a range of non waterlimited ecosystems, including 35 sites of temperate and boreal forests and grasslands, and a tropical plantation (Table 1). Across sites we observed a highly constrained, slightly non-linear relationship between $\mathrm{SR}_{\mathrm{MAT}}$ and $\mathrm{SR}_{\text {annual }}$ (Fig. 4a). Both theoretical considerations and field observations thus confirm the hypothesis that $\mathrm{SR}_{\mathrm{MAT}}$ and $\mathrm{SR}_{\text {annual }}$ are tightly coupled across non water-limited sites. This striking convergence is in principle related to the inherent relationship between these parameters at likely combinations of $T_{\text {sd }}$ and $Q_{10}$ (Fig. 1).

To assess the robustness of our analysis we re-calculated the regression for $\mathrm{SR}_{\mathrm{MAT}}$ versus $\mathrm{SR}_{\text {annual }}$ for the 36 nonwater limited sites leaving out one site at a time (crossvalidation approach). The probability density function for the 36 sites is not significantly different from a normal distribution (using a One-Sample Kolmogorov-Smirnov Test). Then we calculated the related bias for these new estimations. The mean of all the sites is $1.01 \pm 0.159$ (s.d.; minimum $=0.69$; maximum $=1.4$ ). The site that is underestimated is ITex (1998); and the site that is overestimated is Cow Park (UK). The results are not significantly different from the ones that we showed in the initial analysis giving 

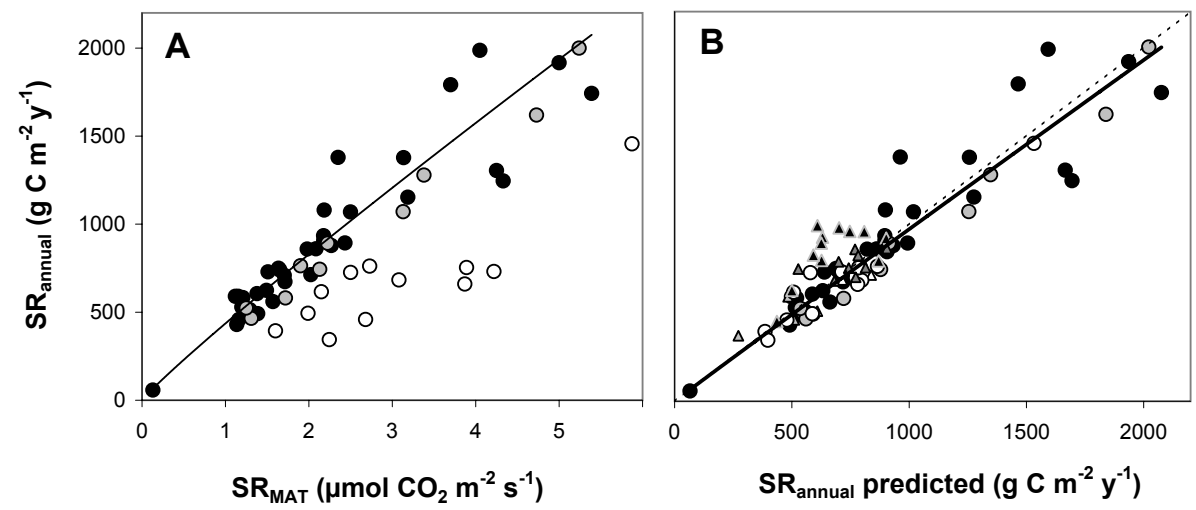

Fig. 4. (A) Relationship between soil respiration at mean annual temperature $\left(\mathrm{SR}_{\mathrm{MAT}}, \mu \mathrm{mol} \mathrm{CO} \mathrm{m}^{-2} \mathrm{~s}^{-1}\right)$ and total annual soil respiration $\left(\mathrm{SR}_{\text {annual }}, \mathrm{g} \mathrm{C} \mathrm{m}^{-2} \mathrm{y}^{-1}\right)$ for 57 forests, plantations, savannas, grasslands and shrublands across boreal, temperate, tropical, mediterranean, dry sub-humid and semi-arid biomes. The regression is based on all 36 sites where precipitation/potential evapotranspiration $(P / \mathrm{PET})$ exceeds 1 and no distinct dry season occurs $(\bullet)\left(\mathrm{SR}_{\text {annual }}=436.2 \mathrm{SR}_{\mathrm{MAT}}^{0.926}, R^{2}=0.94, p<0.001\right)$. Shaded and open circles indicate seasonally dry sites where $\mathrm{SR}_{\text {MAT }}$ was based on annual $(\bullet)$ and wet $(O)$ season data, respectively. (B) Predicted versus observed annual soil respiration for all 80 site-years $\left(\mathrm{SR}_{\text {annual }}\right.$ observed $=1.06 \mathrm{SR}_{\text {annual }}$ predicted $\left.{ }^{0.988}, R^{2}=0.94, p<0.001\right)$. For seasonally dry sites $\mathrm{SR}_{\mathrm{MAT}}$ was corrected by an aridity factor (Fig. 5a) whenever only wet season SR $_{\text {MAT }}$ was available. Dotted line represents the 1:1 line. Symbols as in Fig. 4a. Triangles represent the interannual data for four temperate forest sites, as shown in Fig. 6 ( $\mathbf{\Delta}$ : Harvard 1997-2008, $\Delta$ : Howland 2000-2008, : Hesse 1996-1998, white $\Delta$ : Soroe 1996-1998).

that the mean of the prediction is 1.01 at each particular site when that site is excluded. Therefore this new approach is consistent with our previous results and does not change our conclusions. The $95 \%$ confidence interval of the predictions made with the reported regressions is between $70 \%$ and $132 \%$ of the measured annual total.

We extended our analysis to seasonally dry ecosystems, including 6 seasonally dry tropical rainforests and plantations, and 15 mediterranean, dry sub-humid and semi-arid forests, savannas, grasslands and shrublands (Table 1). Irrespective of site aridity the relationship of $\mathrm{SR}_{\mathrm{MAT}}$ and $\mathrm{SR}_{\text {annual }}$ persisted when MAT occurred during both dry and wet season, which was typically the case for all tropical sites, but also some semi-arid ecosystems (Fig. 4a). Whenever MAT occurred only during the wet season (i.e. when soil temperature exceeded MAT throughout the dry season), observed $\mathrm{SR}_{\text {annual }}$ was lower than would be estimated from $\mathrm{SR}_{\mathrm{MAT}}$. $\mathrm{SR}_{\text {annual }}$ is overestimated from $\mathrm{SR}_{\mathrm{MAT}}$ measured only during the wet season, as its direct inference from $\mathrm{SR}_{\mathrm{MAT}}$ does not account for the fact that during the dry season SR may be substantially reduced due to water limitations. This reduction can be corrected for (Fig. 4b), since it is strongly related to site aridity, as expressed by the ratio P/PET (Fig. 5a) or the number of months when $P / \mathrm{PET}<1$ (Fig. $5 \mathrm{~b}$ ). However, it should be noted that a general aridity index does not account for the interannual variability of precipitation, which may decisively alter seasonal patterns and thus the annual total of SR (Ma et al., 2007). Clearly, more studies are needed that corroborate the relationships of site aridity, $\mathrm{SR}_{\mathrm{MAT}}$ and $\mathrm{SR}_{\text {annual }}$ for seasonally dry ecosystems.
We tested the model output against the observed values (Fig. 4b) using a paired t-test. First, we only used the 36 non water-limited sites with the predicted values from the regression without each one of the sites. There were no significant differences between observed values and predicted $(t=-0.032, P=0.974)$. Then we calculated the changes in the $P /$ PET correction factor, excluding case by case and recalculating the equation. Finally, the predicted annual total SR was recalculated accounting for both changes in the P/PET correction factor and the overall relationship of $\mathrm{SR}_{\mathrm{MAT}}$ and $\mathrm{SR}_{\text {annual }}$ occurring when each of the sites is left out at a time. Again, a paired t-test did not yield any significant differences between measured and predicted values.

We estimated the prediction uncertainty for the overall dataset by calculating the root mean squared error (RMSE). For the whole dataset RMSE was $625 \mathrm{~g} \mathrm{C} \mathrm{m}^{-2} \mathrm{y}^{-1}$ for non water-limited sites, $404 \mathrm{~g} \mathrm{C} \mathrm{m}^{-2} \mathrm{y}^{-1}$ for sites for which an $P /$ PET correction factor was applied, and $618 \mathrm{~g} \mathrm{C} \mathrm{m}^{-2} \mathrm{y}^{-1}$ for all sites. Stratified by four flux levels RMSE was $203 \mathrm{~g} \mathrm{C} \mathrm{m}^{-2} \mathrm{y}^{-1} \quad\left(\mathrm{SR}_{\text {annual }}=0-500 \mathrm{~g} \mathrm{C} \mathrm{m}^{-2} \mathrm{y}^{-1}\right)$, $191 \mathrm{~g} \mathrm{C} \mathrm{m}^{-2} \mathrm{y}^{-1} \quad\left(\mathrm{SR}_{\text {annual }}=500-1000 \mathrm{~g} \mathrm{C} \mathrm{m}^{-2} \mathrm{y}^{-1}\right)$, $300 \mathrm{~g} \mathrm{C} \mathrm{m}^{-2} \mathrm{y}^{-1}\left(\mathrm{SR}_{\text {annual }}=1000-1500 \mathrm{~g} \mathrm{C} \mathrm{m}^{-2} \mathrm{y}^{-1}\right)$ and $262 \mathrm{~g} \mathrm{C} \mathrm{m}^{-2} \mathrm{y}^{-1} \quad\left(\mathrm{SR}_{\text {annual }}=1500-2000 \mathrm{~g} \mathrm{C} \mathrm{m}^{-2} \mathrm{y}^{-1}\right)$, corresponding to a relative error of 51,27, 24 and $14 \%$, respectively. In comparison, within-site uncertainty estimates of annual SR have been reported to be in the range of $9-25 \%$, in some instances even up to $40-90 \%$ of $\mathrm{SR}_{\text {annual }}$ (Bahn et al., 2008). 

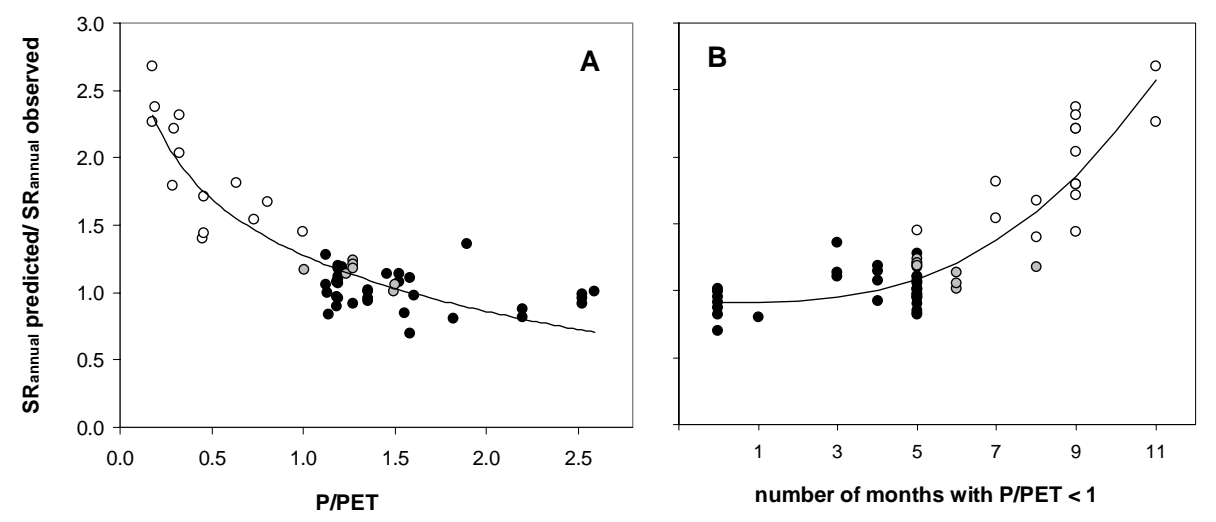

Fig. 5. Ratio of predicted to observed annual soil respiration $\left(\mathrm{SR}_{\text {annual }}\right)$ in relation to site aridity, as expressed by (A) the ratio of precipitation to potential evapotranspiration $(P / \mathrm{PET})$ and $(\mathbf{B})$ the number of dry months $(P / \mathrm{PET}<1)$. Symbols as in Fig. 4 . Regression equations and statistics for (A): $\mathrm{SR}_{\text {annual }}$ predicted/observed $=-0.601 \mathrm{Ln}(P / \mathrm{PET})+1.278, R^{2}=0.82, p<0.001$; for $(\mathrm{B})$ : $\mathrm{SR}_{\text {annual }}$ predicted/observed $=1.9210^{-3} x^{2.823}+0.908$, where $x$ is the number of months with $P / \mathrm{PET}<1\left(R^{2}=0.78, p<0.001\right)$.

\subsection{Interannual variation}

It has been demonstrated that cross-site relationships may not reflect well within-site variability and may thus not be well suitable for deriving estimates for individual sites (for belowground C allocation see e.g. Gower et al., 1996; Litton et al., 2007). As shown above, the inter-site relationship is robust and the $95 \%$ confidence interval of the predictions made with the reported regressions is between $70 \%$ and $132 \%$ of the correct annual total, as based on a cross-validation approach leaving out one site at a time.

Using the cross-site relationship, $\mathrm{SR}_{\mathrm{MAT}}$ obtained across years within a single site predicts $\mathrm{SR}_{\text {annual }}$ similarly as does SR $_{\text {MAT }}$ from across sites (Fig. 4b). RMSE for the two sites with larger number of site years, Howland Forest (9 years) and Harvard Forest (12 years), amounts to 204 and $219 \mathrm{~g} \mathrm{C} \mathrm{m}^{-2} \mathrm{y}^{-1}$, respectively, corresponding to a relative error of $26 \%$ in both cases. Thus, measurement of SR $\mathrm{MAT}_{\mathrm{T}}$ in any of these years would have provided an estimate of $\mathrm{SR}_{\text {annual }}$ within the prediction uncertainty of the cross-site relationship (cf. above). This likely holds also for exceptionally dry years or seasons, as occurred at Harvard forest in 1997 and 1999 (Fig. 6). Nevertheless, it should again be stressed that at arid sites, a fixed correction factor relating to average site aridity, may fail to account for effects caused by a distinct interannual (i.e. year-to-year) variation in precipitation (cf. above).

Figure 6 shows that within-site relationships between $\mathrm{SR}_{\mathrm{MAT}}$ and $\mathrm{SR}_{\text {annual }}$, as based on the available site-years for four temperate forest sites, may or may not follow the trend observed across sites, the slope differing most distinctly for Howland forest, where also only a minor amount of the interannual variation was explained by the regression. This may also have to do with the fact that at this site the interannual variation of $\mathrm{SR}_{\text {annual }}$ was comparatively small (Fig. 6). Thus,

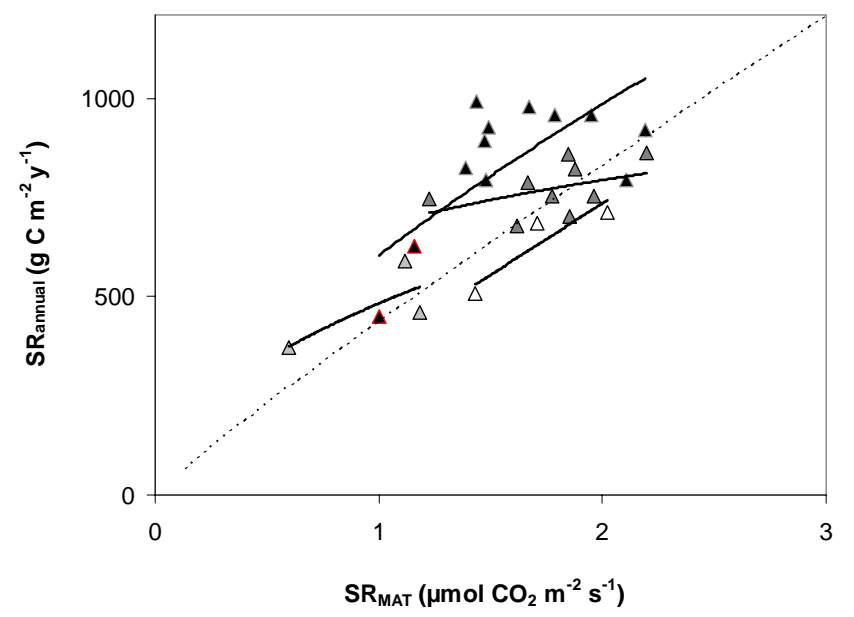

Fig. 6. Interannual variation of soil respiration at mean annual temperature $\left(\mathrm{SR}_{\mathrm{MAT}}, \mu \mathrm{mol} \mathrm{CO} \mathrm{m}^{-2} \mathrm{~s}^{-1}\right)$ and total annual soil respiration $\left(\mathrm{SR}_{\text {annual }}, \mathrm{g} \mathrm{C} \mathrm{m}^{-2} \mathrm{y}^{-1}\right)$ for four temperate forest sites $(\boldsymbol{\Delta}$ : Harvard 1997-2008, A: Howland 2000-2008, _: Hesse 19961998, $\Delta$ : Soroe 1996-1998). Data for Harvard forest include two exceptionally dry summers (marked by red outlines). The dotted line indicates the cross-site relationship between $\mathrm{SR}_{\mathrm{MAT}}$ and $\mathrm{SR}_{\text {annual }}$ data, as shown in Fig. 4a.

the cross-site relationship between $\mathrm{SR}_{\mathrm{MAT}}$ and $\mathrm{SR}_{\text {annual }}$ may not be well suited for estimating the interannual variation of $\mathrm{SR}_{\text {annual }}$, though it may provide an indication of trends if this variation is large. However, such trends are likely obscured by the comparatively large overall prediction uncertainties discussed above. 


\section{General implications and conclusions}

Our findings have implications for assessing the spatial variability of $\mathrm{SR}_{\text {annual }}$. Methodological designs typically face a trade-off between the temporal resolution required to obtain a defensible annual estimate and spatial coverage (Savage and Davidson, 2003), which has up to now resulted in estimates of $\mathrm{SR}_{\text {annual }}$ for a limited number of ecosystems. However, it has been shown that the spatial variability of SR may be at least of similar order of magnitude as the temporal one (Curiel Yuste et al., 2004; Kang et al., 2003; Rayment and Jarvis, 2000), which restricts our potential of estimating SR and its variation on larger spatial scales. The tight relationship between $\mathrm{SR}_{\text {MAT }}$ and $\mathrm{SR}_{\text {annual }}$ indicates that it is sufficient to assess $\mathrm{SR}_{\mathrm{MAT}}$ for obtaining a highly constrained estimate of its annual total (Fig. 4b), as based on a small number of measurements. Such measurements should take into account that $\mathrm{SR}_{\mathrm{MAT}}$ may vary during the year, most obviously for seasonally dry ecosystems (cf. above) but also for non water-limited ecosystems, where SR may be higher in springtime, when rhizosphere activity is high, and comparatively lower in fall (Curiel Yuste et al., 2004; Davidson et al., 2006a). Once available, $\mathrm{SR}_{\mathrm{MAT}}$ not only characterizes the site-specific conditions (including climate and vegetation related effects on productivity and soil organic matter quality) for autotrophic and heterotrophic respiratory $\mathrm{CO}_{2}$ losses, but also permits a direct estimate of $\mathrm{SR}_{\text {annual }}$.

However, it should be noted that estimates for $\mathrm{SR}_{\text {annual }}$ obtained from SR $\mathrm{MAT}$ will inevitably be less accurate than values obtained from episodic or even continuous datasets. The likelihood of detecting significant differences of $\mathrm{SR}_{\text {annual }}$ across sites and, within sites across years, will increase with an increasing variability of $S_{\text {annual }}$. Thus, for assessing $S R$ on larger scales the $\mathrm{SR}_{\mathrm{MAT}}-\mathrm{SR}_{\text {annual }}$ relationship could be applied pursuing a stratified approach, which helps with identifying regional components of larger versus smaller variability in SR. If needed on a more refined scale, sites characterized by smaller variability can then be analysed in more detail, implementing more elaborate and time-consuming studies.

We conclude that soil respiration at mean annual temperature is a suitable predictor of its annual total across vegetation types and biomes. This should substantially increase our capacity for assessing the spatial distribution of annual soil $\mathrm{CO}_{2}$ emissions across ecosystems, landscapes and regions, and thereby contribute to improving the spatial resolution of a major component of the global carbon cycle.
Acknowledgements. We thank all site PIs of the FLUXNET LaThuile synthesis (www.fluxdat.org) who have permitted using their soil temperature data to calculate typical ranges of $T_{\mathrm{sd}}$. We acknowledge comments on an earlier version of this manuscript by Mike Ryan and two anonymous reviewers. Data synthesis was supported by the Austrian Science Fund (FWF) grant P18756-B16 to MB. MR acknowledges funding from the European Research Council to the QUASOM project (ERC-2007-StG-208516).

Edited by: V. Brovkin

\section{References}

Bahn, M., Rodeghiero, M., Anderson-Dunn, M., Dore, S., Gimeno, C., Drosler, M., Williams, M., Ammann, C., Berninger, F., Flechard, C., Jones, S., Balzarolo, M., Kumar, S., Newesely, C., Priwitzer, T., Raschi, A., Siegwolf, R., Susiluoto, S., Tenhunen, J., Wohlfahrt, G., and Cernusca, A.: Soil Respiration in European Grasslands in Relation to Climate and Assimilate Supply, Ecosystems, 11, 1352-1367, 2008.

Bahn, M., Kutsch, W., and Heinemeyer, A.: Synthesis: Emerging issues and challenges for an integrated understanding of soil carbon fluxes, in: Soil Carbon Dynamics, an Integrated Methodology, Cambridge Univ. Press, Cambridge, 257-271, 2009.

Bahn, M., Janssens, I. A., Reichstein, M., Smith, P., and Trumbore, S.: Soil respiration across scales: towards an integration of patterns and processes, New Phytol., 186, 292-296, 2010.

Baldocchi, D.: Breathing of the terrestrial biosphere: lessons learned from a global network of carbon dioxide flux measurement systems, Austr. J. Bot., 56, 1-26, 2008.

Bond-Lamberty, B. and Thomson, A.: Temperature-associated increases in the global soil respiration record, Nature, 464, 579$583,2010$.

Carbone, M., Winston, G., and Trumbore, S.: Soil respiration in perennial grass and shrub ecosystems: Linking environmental controls with plant and microbial sources on seasonal and diel timescales, J. Geophys. Res.-Atmos., 113, G02022, doi:10.1029/2007JG000611, 2008.

Curiel Yuste, J., Janssens, I. A., Carrara, A., and Ceulemans, R.: Annual $Q_{10}$ of soil respiration reflects plant phenological patterns as well as temperature sensitivity, Global Change Biol., 10, 161-169, 2004.

Davidson, E. A., Verchot, L. V., Cattanio, J. H., Ackerman, I. L., and Carvalho, J. E. M.: Effects of soil water content on soil respiration in forests and cattle pastures of eastern Amazonia, Biogeochemistry, 48, 53-69, 2000.

Davidson, E. A., Savage, K., Bolstad, P., Clark, D. A., Curtis, P. S., Ellsworth, D. S., Hanson, P. J., Law, B. E., Luo, Y., Pregitzer, K. S., Randolph, J. C., and Zak, D.: Belowground carbon allocation in forests estimated from litterfall and IRGA-based soil respiration measurements, Agr. Forest Meteorol., 113, 39-51, 2002.

Davidson, E. A., Janssens, I. A., and Luo, Y.: On the variability of respiration in terrestrial ecosystems: moving beyond $Q_{10}$, Global Change Biol., 12, 154-164, 2006a.

Davidson, E. A., Richardson, A. D., Savage, K. E., and Hollinger, D. Y.: A distinct seasonal pattern of the ratio of soil respiration to total ecosystem respiration in a spruce-dominated forest, Global Change Biol., 12, 230-239, 2006 b. 
Davidson, E. A., Savage, K. E., Trumbore, S. E., and Borken, W.: Vertical partitioning of $\mathrm{CO}_{2}$ production within a temperate forest soil, Global Change Biol., 12, 944-956, 2006c.

Davidson, E. A., Nepstad, D. C., Ishida, F. Y., and Brando, P. M.: Effects of an experimental drought and recovery on soil emissions of carbon dioxide, methane, nitrous oxide, and nitric oxide in a moist tropical forest, Global Change Biol., 14, 2582-2590, 2008.

Denman, K. L., Brasseur, G., Chidthaisong, A., Ciais, P., Cox, P. M., Dickinson, R. E., Hauglustaine, D., Heinze, C., Holland, E., Jacob, D., Lohmann, U., Ramachandran, S., da Silva Dias, P. L., Wofsy, S. C., and Zhang, X.: Couplings Between Changes in the Climate System and Biogeochemistry, in: Climate Change 2007: The Physical Science Basis, Contribution of Working Group I to the Fourth Assessment Report of the Intergovernmental Panel on Climate Change, Cambridge Univ. Press, Cambridge, 499-587, 2007.

Droogers, P. and Allen, R. G.: Estimating Reference Evapotranspiration Under Inaccurate Data Conditions, Irrig. Drain., 16, 3345, 2002.

Gower, S. T., Pongracic, S., and Landsberg, J. J.: A global trend in belowground carbon allocation: can we use the relationship at smaller scales?, Ecology, 77, 1750-1755, 1996.

Grünzweig, J. M., Hemming, D., Maseyk, K., Lin, T. B., Rotenberg, E., Raz-Yaseef, N., Falloon, P. D., and Yakir, D.: Water limitation to soil $\mathrm{CO}_{2}$ efflux in a pine forest at the semiarid "timberline", $\mathrm{J}$. Geophys. Res.-Biogeo., 114, doi:10.1029/2008jg000874, 2009.

Hibbard, K. A., Law, B. E., Reichstein, M., and Sulzman, J.: An analysis of soil respiration across northern hemisphere temperate ecosystems, Biogeochemistry, 73, 29-70, 2005.

Janssens, I. A., Lankreijer, H., Matteucci, G., Kowalski, A. S., Buchmann, N., Epron, D., Pilegaard, K., Kutsch, W., Longdoz, B., Grunwald, T., Montagnani, L., Dore, S., Rebmann, C., Moors, E. J., Grelle, A., Rannik, U., Morgenstern, K., Oltchev, S., Clement, R., Gudmundsson, J., Minerbi, S., Berbigier, P., Ibrom, A., Moncrieff, J., Aubinet, M., Bernhofer, C., Jensen, N. O., Vesala, T., Granier, A., Schulze, E. D., Lindroth, A., Dolman, A. J., Jarvis, P. G., Ceulemans, R., and Valentini, R.: Productivity overshadows temperature in determining soil and ecosystem respiration across European forests, Global Change Biol., 7, 269278, 2001.

Janssens, I. A., Dore, S., Epron, D., Lankreijer, H., Buchmann, N., Longdoz, B., Brossaud, J., and Montagnani, L.: Climatic influences on seasonal and spatial differences in soil $\mathrm{CO}_{2}$ efflux, in: Fluxes of carbon, water and energy of European forests, Springer-Verlag, Berlin-Heidelberg, 2003.

Janssens, I. A. and Pilegaard, K.: Large seasonal changes in $Q_{10}$ of soil respiration in a beech forest, Global Change Biol., 9, 911918, 2003.

Kang, S., Doh, S., Dongsun, L., Dowon, L., Jin, V. L., and Kimball, J. S.: Topographic and climatic controls on soil respiration in six temperate mixed-hardwood forest slopes, Korea, Global Change Biol., 9, 1427-1437, 2003.

Kirschbaum, M. U. F.: The temperature dependence of organicmatter decomposition - still a topic of debate, Soil Biol. Biochem., 38, 2510-2518, 2006.

Litton, C. M., Ryan, M. G., and Raich, J. W.: Carbon allocation in forest ecosystems, Global Change Biol., 13, 2089-2109, 2007.
Ma, S. Y., Baldocchi, D. D., Xu, L. K., and Hehn, T.: Inter-annual variability in carbon dioxide exchange of an oak/grass savanna and open grassland in California, Agr. Forest Meteorol., 147, 157-171, 2007.

New, M., Lister, D., Hulme, M., and Makin, I.: A high-resolution data set of surface climate over global land areas, Clim. Res., 21, $1-25,2002$.

Österle, H., Gerstengarbe, F. W., and Werner, P. C.: Homogenisierung und Aktualisierung des Klimadatensatzes der Climate Research Unit of East Anglia, Norwich, Terra Nostra, 6, 326-329, 2003.

Raich, J. W. and Nadelhoffer, K. J.: Belowground carbon allocation in forest ecosystems: Global trends, Ecology, 70, 1346-1354, 1989.

Raich, J. W. and Potter, C. S.: Global Patterns of Carbon Dioxide Emissions from Soils, Global Biogeochem. Cy., 9, 23-26, 1995.

Raich, J. W., Potter, C. S., and Bhagawati, D.: Interannual variability in global soil respiration, 1980-94, Global Change Biol., 8, 800-812, 2002.

Rayment, M. B. and Jarvis, P. G.: An improved open chamber system for measuring soil $\mathrm{CO}_{2}$ effluxes in the field, J. Geophys. Res.-Atmos., 102, 28779-28784, 1997.

Rayment, M. B. and Jarvis, P. G.: Temporal and spatial variation of soil $\mathrm{CO}_{2}$ efflux in a Canadian boreal forest, Soil Biol. Biochem., 32, 35-45, 2000.

Reichstein, M., Rey, A., Freibauer, A., Tenhunen, J., Valentini, R., Banza, J., Casals, P., Cheng, Y., Grünzweig, J., Irvine, J., Joffre, R., Law, B., Loustau, D., Miglietta, F., Oechel, W., Ourcival, J.M., Pereira, J., Peressotti, A., Ponti, F., Qi, Y., Rambal, S., Rayment, M., Romanya, J., Rossi, F., Tedeschi, V., Tirone, G., Xu, M., and Yakir, D.: Modelling temporal and large-scale spatial variability of soil respiration from soil water availability, temperature and vegetation productivity indices, Global Biogeochem. Cy., 17, 1104, doi:10.1029/2003GB002035, 2003.

Salimon, C. I., Davidson, E. A., Victoria, R. L., and Melo, A. W. F.: $\mathrm{CO}_{2}$ flux from soil in pastures and forests in southwestern Amazonia, Global Change Biol., 10, 833-843, 2004.

Savage, K., Davidson, E. A., Richardson, A. D., and Hollinger, D. Y.: Three scales of temporal resolution from automated soil respiration measurements, Agr. Forest Meteorol., 149, 2012-2021, 2009.

Savage, K. E. and Davidson, E. A.: A comparison of manual and automated systems for soil $\mathrm{CO}_{2}$ flux measurements: trade-offs between spatial and temporal resolution, J. Exp. Bot., 54, 891899, 2003.

Tang, J. W. and Baldocchi, D. D.: Spatial-temporal variation in soil respiration in an oak-grass savanna ecosystem in California and its partitioning into autotrophic and heterotrophic components, Biogeochemistry, 73, 183-207, 2005.

Trumbore, S.: Carbon respired by terrestrial ecosystems - recent progress and challenges, Global Change Biol., 12, 141-153, 2006.

Vargas, R. and Allen, M. F.: Environmental controls and the influence of vegetation type, fine roots and rhizomorphs on diel and seasonal variation in soil respiration, New Phytol., 179, 460-471, 2008. 
Vargas, R., Detto, M., Baldocchi, D. D., and Allen, M. F.: Multiscale analysis of temporal variability of soil $\mathrm{CO}_{2}$ production as influenced by weather and vegetation, Global Change Biol., 16, 1589-1605, 2010.

Vincent, G., Shahriari, A. R., Lucot, E., Badot, P.-M., and Epron, D.: Spatial and seasonal variations in soil respiration in a temperate deciduous forest with fluctuating water table, Soil Biol. Biochem., 38, 2527-2535, 2006.
Wieser, G., Gruber, A., Bahn, M., Catala, E., Carrillo, E., Jimenez, M. S., and Morales, D.: Respiratory fluxes in a Canary Islands pine forest, Tree Physiol., 29, 457-466, 2009. 